\title{
Requirements for Reaching the Sustainable Goals of Development to Plan New Areas in Arab Republic of Egypt
}

\author{
Nourhan Aly Fawzy*, Sammy Amin Ammer, Ebtehal Ahmed Abd Elmouety \\ Regional Planning Department, Faculty of Urban and Regional Planning, Cairo University, Cairo University Campus, Gamaa \\ Street, Giza 12613, Egypt
}

Corresponding Author Email: nouraly2m@gmail.com

https://doi.org/10.18280/ijsdp.160319

Received: 22 August 2020

Accepted: 18 December 2020

\section{Keywords:}

new area, sustainable development, sustainable development goals, planning new areas, sustainable development dimensions

\begin{abstract}
Egypt has many new areas, most of which are found outside the boundaries of urbanization in the valley and delta. Such areas contain capabilities and ingredients with special natural and environmental features that differ from the built-up areas. As development areas have been recently created by the development policies and strategies which were put forward by the country to accommodate sustainable development processes. There is an Availability of suitable areas for development according to resources and without limitations, which amount to $24 \%$ of the total area. There are, also, suitable areas for development according to resources with the presence of some limitations, which amount to an area of $16 \%$ of the total area. Sustainable development captures the world's attention during the past 15 years, at the level of the global economic, social and environmental field. Thus, development sustainability has become a global school of thought that spreads in most of the countries of the world, All UN member states adopted the Sustainable Development Goals in 2015 as the main umbrella for balancing social, economic, and environmental sustainability by 2030. And also the plans put forward in Egypt The research discusses what are the Requirements for reaching the sustainable goals of development to plan new areas in Arab Republic of Egypt. By using qualitative methods Because these areas have a shortage of statistical data. To can reach, foundations and indicators for sustainable development, adopting a national sustainable development strategy that includes all entities, institutions, members of society and those affected by its results in the short and long term.
\end{abstract}

\section{INTRODUCTION}

Today, the world has become convinced that sustainable development that eliminates backwardness issues is the only way to ensure access to the essentials of life now and in the future. The SDGs that were introduced by The UN program "UNDP" is a global call for action to eradicate poverty, protect the planet and ensure its enjoyment all people are peaceful and prosperous, Poverty in Arab countries accounts for $40.6 \%$ of the population and Egypt's poverty rate is $29.7 \%$ [1, 2]. And new fields such as climate change, economic inequality, the rate of economic growth in Egypt is 5.6\% in 2019 and promoting innovation, Egypt is at number 92 in terms of the global innovation index. and sustainable consumption are also included [3, 4]. The goals most countries seek, especially developing countries like Egypt, are the targets they represent [5].

Egypt faces a host of challenges that impede sustainable development where the Egyptian borders constitute a large area about one million square kilometers, which $92.17 \%$ of this space is uninhabited, and $97.8 \%$ of the population of Egypt is concentrated in a limited area not exceeding $7.83 \%$ of the total national space [6]. The challenges that have hampered development processes and affected them are many the relationships between man and man with all his abilities and abilities the place is with all its capabilities and its limitations
[7].

So, the issue requires to come out to new broad horizons outside the valley (the uninhabited areas), with unexploited constituents and development did not enter in the required Form [5, 8]. These areas represent (new promising areas) characterized by their ability to achieve future development in an optimal way [9]. Sustainability is a development style characterized by rationality, which deals with economic activities aimed at growth on the first hand, and with measures to conserve the environment and natural resources on the other hand [10].

The current development trends have been carefully taken into new areas account the sustainability of development process, to ensure the future of future generations [11]. The country's orientation and plan that addressed the ideas of sustainable development (sustainable development strategy in Egypt Vision 2030), did not take into account Indicators for measuring long-term achievement of sustainable development goals, Do not set indicators for new areas to suit this privacy areas (environmental - economic - community characteristics) As one of the proposed solutions for reducing the effects of growth in existing areas, and not subtracting the risk assessment when projects are settled in these areas. And also SDGs did not take into account the specificity of these areas [12]. 
So, the research gap is the incomplementarity of the SDGs and the privacy of new areas in the development plans put forward by the State For these areas.

The research aims to define the requirements for achieving the sustainable development goals in these new areas, and establish a series well pondered set of extend indicators "framework" that could be used to analyze the SDGs in new areas. To rely on new areas (the developmental scale), to accommodate the requirements of sustainable development. The resources and components of these areas are being used to settle development projects in all sectors to create new prospects for sustainable development. Its efficiency is measured by extend indicators from SDGs.

\section{MATERIALS AND METHODS}

The research is considered as evidentiary research. The sustainable development goals are the primary goals that all countries should pursue when developing plans and strategic visions, as a way to reduce the gap between developing and developed countries, and the link between current and next generation. Thus, to ensure the continuity of human life and equitable distribution of resources [13]. The research relies on qualitative or creative methods that use the deductive approach to take advantage of the theoretical literature for sustainable development [14]. To be careful because these areas have a shortage of statistical data. To determine the role of the new areas in achieving the sustainable development goals, this is done by defining the requirements for achieving these goals according to the basic dimensions of sustainable development (socio-economic-environmental and technological) [15]. Taking into account the specific dimensions of these areas (characteristics of the community - scarcity of resources and their absorptive capacity - management of development biodiversity - ....). By making special key indicators to measure indicators of sustainable development in new areas under the umbrella of objectives to sustainability. Figure 1 shows the research methodology.

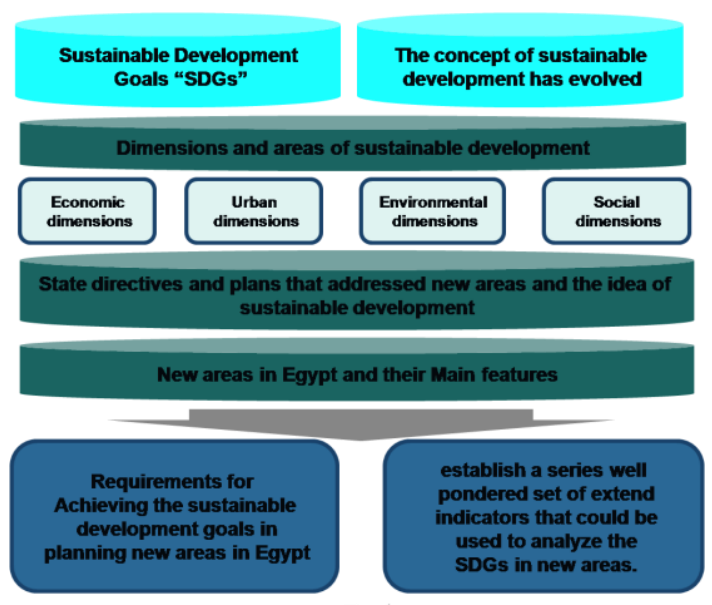

Figure 1. Methodological phases of the research

\section{RESULTS AND DISCUSSION}

\subsection{The concept of sustainable development}

The concepts of sustainable development have varied from the very beginning of their appearance and interest in them during the period (1980s, 1990s and early twentieth century). Proposed by international institutions and organizations. Which agreed that; Sustainable Development is defined as such development that meets the needs of people today without compromising the ability of future generations to achieve their goals. And it focuses on sustainable integrated economic growth, environmental stewardship, and social responsibility [16].

Thus, Sustainable development is the process of developing land, cities and societies, as well as business, provided that it meets the needs of the present without compromising the ability of future generations to meet their needs $[17,18]$.

By reading and analyzing the multiple concepts of sustainable development, it is possible to draw A concept for developing new areas from a researcher's point of view: However, it is a multi-purpose suite of programs and policies to bring about a series of dynamic changes to improve, regulate and sustain the exploitation and development of disabled assets and resources available (natural-human) in accordance with the region's promising characteristics (environmental- community-age-economic) To bring about comprehensive change and create new development entities in all areas (Economic-physical-social) integration of different planning levels (national-regional-local).

Or is the desired development in all its forms (economic/social/urban development...) these are integrated with the resources available in an area (agricultural/industrial/mining/tourism ...) A plan to maximize the return on these resources is a new starting point for development.

\subsection{The sustainable development goals}

The Sustainable Development Goals "SDGs" are built on the success of the Millennium Development Goals (MDGs), and they aim to move forward to end all forms of poverty. The new goals are unique, that they invite all poor, rich, and middle-income countries to work for promoting prosperity, while at the same time it is protecting the universe. It also recognizes that ending poverty must be in line with strategies that build economic growth and address a range of social needs, including education, health, social protection, and job creation, while addressing climate change and environmental protection [12]. Figure 2 shows the sustainable development goals that reflect the areas of development (economic - social environmental and technological).

The researcher concludes the Sustainable Development Goals for the new areas: $[15,19,20]$.

-Stimulating and sustaining the economy at different levels through the development of new areas.

- Optimize the use of available resources to ensure their sustainability and satisfy basic needs.

- The integrated promotion of all aspects of social, economic and physical life.

- A healthy, age-old environment at all planning levels.

- Creating new development and investment opportunities in all areas that attract international and national investment.

-Drive and motivate local communities to participate in development processes.

- Contribution to the handling of the Egyptian tiger cases.

- To work to improve the quality of life in accordance with the efficient use of resources and to leverage investments within the absorptive capacity of the ecosystem [21]. 
-Taking into account global variables, technological development, and the potential to be exploited to create competitive and sophisticated activities that suit these variables and make optimal use of available resources.

-Optimal employment of production components (natural resources - labor - capital - technology - interrelationships and relationships between regions and activities)

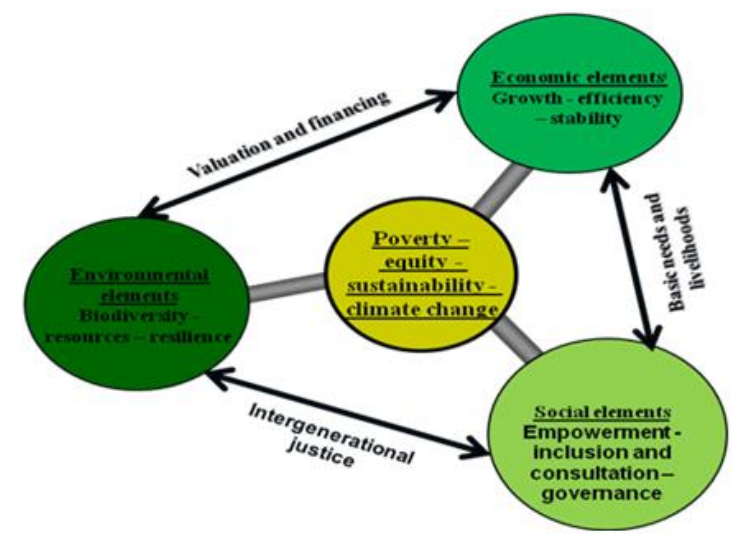

Figure 2. Sustainable development goals

\subsection{Dimensions and areas of sustainable development}

Sustainable development is the link between economic, environmental and social development, so a good circle is created between the three dimensions, economically effective, socially just, and environmentally possible. The basic development dimensions of sustainable development (economic-social-environmental and technological-the urban dimension) are represented. Thus, sustainable development achieves the full link between these dimensions, achieving balance and complementarily between them. As, these components cannot be viewed separately [12, 22, 23]. The areas and dimensions of sustainable development that must be taken into account are those that must be taken into account when promoting it Development of new areas according to their privacy in:

-Social dimensions: This can be achieved through the availability of local executive departments and institutions, through which social, economic and environmental development policies are drawn and applied [24]. Here, providing a cultural structure must be given, which should be compatible with society through changing consumption patterns and reducing waste and recycling resources through a special social nature practices [25].

-Economic dimensions: we should take care of diversity in economic base activities with Integrative relations, with the flexibility to change them to achieve self-reliance as a strategic goal instead of using the export base model outside the regions in light of the difficulty of predicting the form of environmental balances after adding large-size inputs to the urban environmental system. Also, we have to reconsider the traditional thought that focuses on agricultural development as a basis for developing regions, due to the relative scarcity of water resources [26].

-Environmental and technological dimensions: As finding alternative means or alternative energy and clean technological uses to prevent environmental degradation and preserving the unity of the ecosystem [23]. It should take inconsideration: the impact of development activities on the environment and combining development requirements with environmental requirements. Through [27]:

-Resettlement of activities in a manner that does not disruption system regularity and sustainability, and does not degrade the environment.

-Determining activities based on the extent of absorption and capacity of the environment, as the intensity and strength of activities are not constant.

-The ability to influence activities is one of the important factors to determine their impact (the age of the ecosystem or the period of waste emission in any system), where some environments can accommodate some of the outputs for a limited period [28].

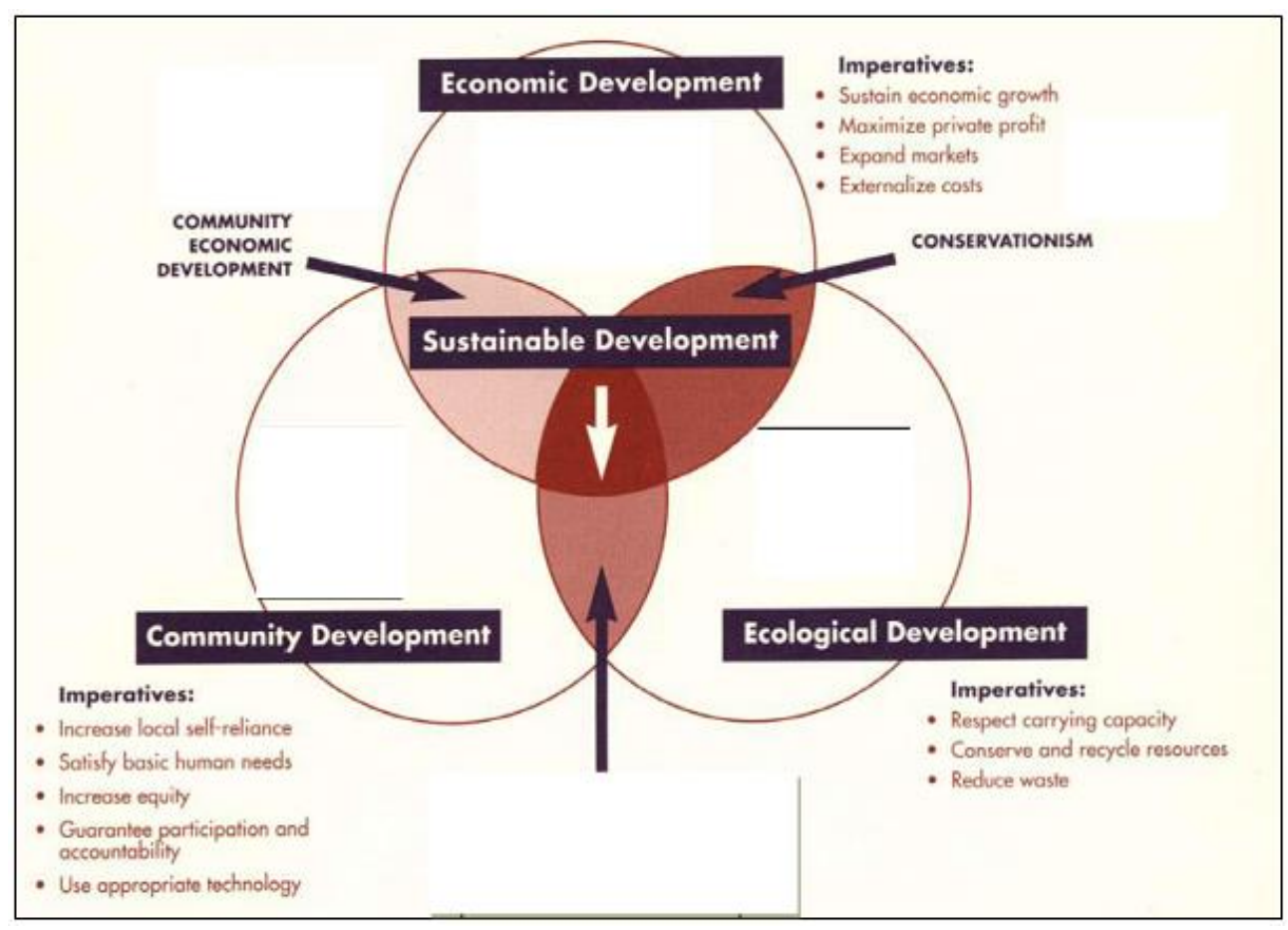

Figure 3. The relationship between dimensions of sustainable development 
Table 1. Sustainable development indicators

\begin{tabular}{|c|c|c|}
\hline $\begin{array}{c}\text { Environmental and technological } \\
\text { dimensions }\end{array}$ & Economic dimensions & Social dimention \\
\hline $\begin{array}{l}\text {-availability of specialized technical labor. } \\
\text { - size of advanced educational institutions, } \\
\text {-availability of knowledge and technology } \\
\text { zones. } \\
\text {-average per capita share of total cultivated } \\
\text { land. } \\
\text { - Water resources available in the region and } \\
\text { per capita share of the region. } \\
\text {-availability of new and renewable energy- } \\
\text { use projects. } \\
\text {-availability of new and renewable } \\
\text { energy resources }\end{array}$ & $\begin{array}{l}\text { - per capita GDP. } \\
\text { - Gross investment/GDP ratio } \\
\text { - Current account balance as a percentage of gross } \\
\text { product. } \\
\text { - Net development assistance as a percentage of } \\
\text { GDP. } \\
\text { - Per capita and region's share of the country's } \\
\text { investment plan. } \\
\text { - provides investment and foreign trade } \\
\text { attractions from airports, ports and free } \\
\text { zones. }\end{array}$ & $\begin{array}{l}\text { - Human poverty indicator. } \\
\text { - Unemployment rate. } \\
\text { - Population growth rate. } \\
\text { - Illiteracy rate. } \\
\text { - The Human Development Index } \\
\text { (HDI) } \\
\text {-Population assimilation. } \\
\text { - Human resources and } \\
\text { population-leading } \\
\text { activities }\end{array}$ \\
\hline
\end{tabular}

-Taking in consideration the mutual effects between the different activities, not consuming them, and assessing the environmental impact of these activities

-Urban dimension: The urban dimension represents the spatial scope to accommodate sustainable development processes in all fields (social-economic-environmental and technological). As, sustainable urban development is achieved through the ability of the development areas' ability to absorb population and resources, and to raise the level of quality of the urban environment $[18,29]$. It is necessary to consider the focus on spatially spreading development rather than concentrating investments in huge units due to the scarcity of resources in the desert environment and spatial dispersal. The issue requires similar responses in the spatial distributions of the urban network in order to express the urban ecology, which requires finding spatially independent development nuclei.

The researcher sees that, Integration and interdependence of the economic, social and environmental dimensions are the basis for sustainable development in the new areas as the spatial scale of the physical dimension of sustainable development. Figure 3 shows the relationship between dimensions of Sustainable development.

The most important indicators that can be applied to new areas can also to measure its ability to achieve Sustainable development goals in new areas.

\subsection{The country's orientations and plans that addressed the new areas and the ideas of sustainable development}

Although the emergence of sustainable development ideas and goals of SDGs since 2015, these objectives were not considered by the plans and trends presented by the country, and these goals did not take into account the development of standard indicators for the new regions and their focus on the existing ones only. The problems and challenges facing Egypt's development process have therefore been exacerbated: [30]. So the sustainable development of new areas is an imperative need to reduce the effects of growth in the existing areas.

The potential to accommodate the requirements of sustainable development is taken into account the risk assessment of Settlement of projects in these areas.

- Population inflation, with population growth rates rising in the Republic from $2.04 \%$ during the period of pluralism (2006/1996) to $2.41 \%$ during the period of pluralism (2015/2006). With the population growth rate continuing at $2.41 \%$ per year, 207.3 million people will be affected by 2050 [31].

- The rate of encroachment on the agricultural sector has increased by more than 120,000 Acres per year [32].

- The increase in food gap and the continuous decrease in food sufficiency rates, by $70.1 \%$, which represents the decrease in the capacity of agricultural land available to achieve the sufficiency of the population needs [33, 34].

- increasing poverty and the average poverty rate of the Republic represents $26.7 \%$ in 2017 . The proportion of the population below the extreme poverty line was $4.4 \%$ in 2017 [11].

- waste of water resources and declining per capita water, Egypt ranks among the poor countries in water resources, with per capita water in $1980\left(900 \mathrm{~m}^{3}\right)$ the water poverty line falling to $600 \mathrm{~m}^{3}$ in 2017 .

Table 1 clarifies the Sustainable development indicators. Which make balance between all dimensions.

- Climate changes, global pollution issues and the expected effects on the Nile by reducing the flow of Nile water to 2040, will negatively affect both food and water security and energy production, and $14 \%$ increase the water needs of crops $[35,36]$

- Economic activity has slowed: Economic growth averaged about $2 \%$ per year during the period 2015-2017, down from $2.6 \%$ in the same period, which means a decline in average per capita income, and economic growth from $6.3 \%$ to $2.1 \%$. This shows that activities and projects that exploit the potential of the Egyptian economy are not settled efficiently.

- Egypt's decline in the global competitiveness index. Egypt's 2015/2016 ranking was about 116 of 140 countries. Egypt ranked 81st of 139 countries in 2010-2011. This is due to the instability facing the Egyptian economy, the failure to offer new development prospects through development plans aimed at competitiveness and reliance on traditional activities and projects [37].

But the importance of employing new areas emerged in the formulation of current development plans and directions, as, the plans and strategies put forward by the state contribute in achieving the goals of sustainable development and follow up their implementation and evaluation [11]. It is known that Egypt announced the (Sustainable Development StrategyVision 2030), through the Ministry of Planning, Follow-up and Administrative Reform. This strategy represents a road map for the future of Egypt and its people. This strategy included the three dimensions of sustainable development [38]. To achieve development, it should establish a series well pondered set of extend indicators under the umbrella of the Un SDGs in new areas.

\subsection{New areas in Egypt}

New areas are considered development areas with special 
features (environmentally, economically, technologically and socially) [39]. New areas can exist as development centers within the planning boundaries of the regions, which are drawn on the basis of the available resources and resources' scope, and in line with the natural and environmental characteristics of the site. Thus, they represent active entities with a diversity environments and ecosystems (boundaries areas, coastal areas, indoor and outdoor area) of a great importance, but they did not receive enough care in the past. And, it contains ready-made ingredients from the resources and capabilities that need to be exploited to make the best use of them. In this way, it is ensured that they will have a role in achieving sustainable development returns in all fields, Nationally, Regionally, or Locally [40]. Thus, they are considered to be of great importance for development while dealing with them cautiously and avoiding the current problems facing the Egyptian society in order to meet the requirements of sustainable development of these areas of nature Private. Figure 4 shows locations of the new areas on Egypt map, which were put up by the author based on a set of measurable criteria.

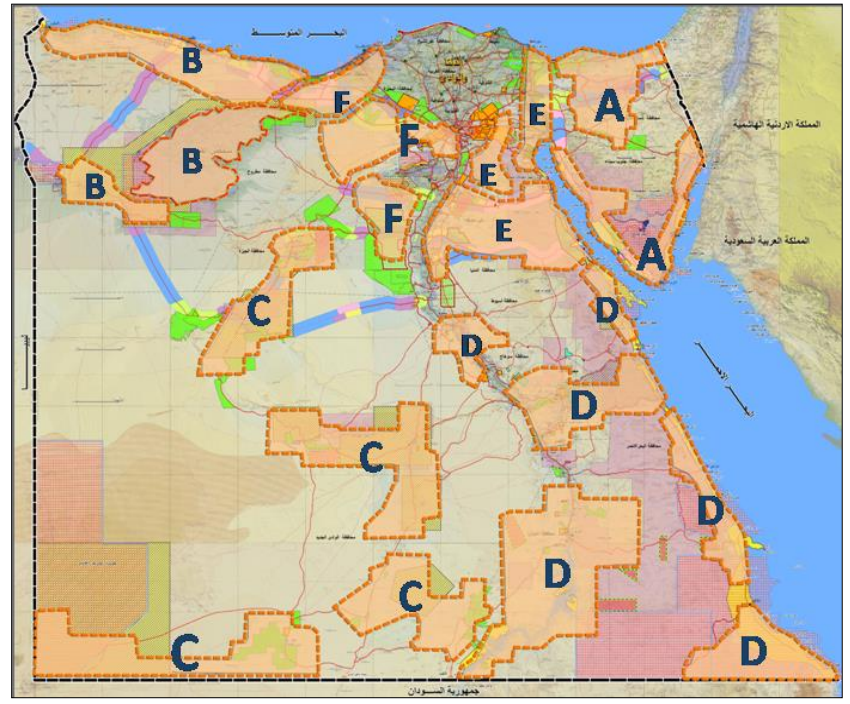

Figure 4. Locations of the new areas in Egypt

\subsection{The current main features of new areas in Egypt}

There was no identification for new areas in Egypt until the end of this century, although of global and regional changes. The main features of the current status of new areas in Egypt which Reflecting The importance of new areas to achieving the SDGs is emerging for their privacy through the capacity of these areas to:

-High population growth rates in the new areas, which range between (2.7 to $3.5 \%$ ), especially in the regions (North SinaiNorthwest of North Coast-East Cairo-West Delta) [41].

-Low per capita from agricultural land, which reaches $(0.11$ acres) as a result of the creeping of non-agricultural buildings, projects and services on agricultural lands and weakness of agricultural investments directed to these areas.
-Decrease in the volume of investments directed to new regions, compared to other regions, especially the major urban regions, which represent $14.2 \%$ of the total volume of investments at in the whole Republic (Egypt's Five-Year Plan 1982 - 2002) [42].

-Increasing poverty rate which reaches more than $40 \%$, especially in the regions (North Sinai-New Valley oasesSouthern Egypt). It is greater than the average of poverty rate in the Republic, determined at $26.3 \%$ [11].

-The human development index decreased to (less than 0.6) compared to the average of the Republic (0.75), which express an average of three main dimensions (life expectancy index as a health indicator, education index as an education index, gross domestic product index as an income index) [43].

-The relative spatial isolation of some regions, as in Sinai in south of Western desert, as a result of (topography and morphology - closure and difficulty in accessing it - the widening distance between the region and other regions) [44].

-Dependence on development and exploitation of new areas and population expansion outside the valley and the delta by (land reclamation and agricultural development projects, most of which are concentrated in the Western Desert, represented in "Toshka, the canal of peace east of the Suez Canal, east of Al-Uwaynat, Darb Al-Arba'een" -new cities-villages of the desert back). Thus, there is no

diversity in the dimensions of development, where we find dependence on one activity, which is agriculture [45].

-Availability of urban growth capabilities (developmental axes and human settlements outside the valley and delta in the Western Desert and Sinai-directing beach development to a sustainable coastal development with a depth of (100-120 m) and settling development activities consistent with spatial

constituents - new urban gatherings-cities and tourist centers on the Red Sea coast and the northern coast) [46].

-Areas with an open population growth pattern that allows absorbing the increase in population. This pattern is represented in the (northern coast, Matrouh-peninsula of Sinai-southern Egypt and New Valley - Red Sea), currently unoccupied in a suitable degree with its resources. It is characterized by its very low population densities (0.07) u / acre [47].

-Multiplicity and diversity of patterns in the new regions: as in (Sinai and Marsa Matrouh, which is considered one of The Periphery States or border regions- east and west of the delta, which is considered one of the centers of The Core Statescoastal areas as in the Red Sea and Northwest Coast) [39].

The importance of the new areas in accommodating sustainable development needs would thus be demonstrated and improving the current situation of Egyptian society through:

The settlement of projects that take into account the different nature, absorptive capacity and sustainability of these areas. Table 2 clarifies development projects in new areas.

- Potential for absorption of new population areas, which represent $37 \%$ of the projected population increase in 2030.

- Create jobs in all areas where $29 \%$ of are accommodated the number of projected employment in 2030. 
Table 2. Development projects in new areas

\begin{tabular}{|c|c|}
\hline Areas & Development projects \\
\hline $\mathbf{A}$ & $\begin{array}{l}\text {-23,5 thousand feddans were reclaimed in Alaml -Altor } \\
\text { - Development of North Sinai - Reclamation of } 400,000 \text { feddans and residence A set of supporting projects } \\
\text { - Tourism development of central Sinai (Beach tourism with a view of the Gulf of Suez and a city Head of the Department's } \\
\text { main tourist development center - Safari Travel in the central part of the province is in the arthroes and mountain valleys } \\
\text { - Industrial zone in Abu Zniema }\end{array}$ \\
\hline $\mathbf{B}$ & $\begin{array}{l}\text { - Create an environmentally compatible city that provides high levels of quality of life Environmental best practices are } \\
\text { applied, especially when supplying infrastructure facilities, (Use of new and renewable sources of energy - use of } \\
\text { desalination and reuse technology - provision of adequate open and green areas - recycling of solid waste - creation of a } \\
\text { sophisticated urban environment - creation of an environmentally friendly industrial zone). } \\
\text { - } 50 \text { thousand feddans were reclaimed in Al-Maghra village } \\
\text { - Ggreatest future Population growth based on new energy and desalination of seawater. } \\
\text { - Development of the North-West Coast and its desert emergence as a destination for world tourism (Eco-friendly } \\
\text { residential city - International leisure center - World Center for healing and War injuries - an International Scientific and } \\
\text { University City - Advanced industrial environmental zone) }\end{array}$ \\
\hline $\mathbf{C}$ & $\begin{array}{l}\text {-The reclamation of } 152,000 \text { feddans in Tuchki and the reclamation of } 265,000 \text { thousand Acres in Alfrafra } \\
\text { - an eco-tourism and renewable energy center, an ideal center for solar power generation worldwide. }\end{array}$ \\
\hline$\overline{\mathbf{D}}$ & $\begin{array}{l}\text { - establishment of the Industrial mining complex (Safaga - Qasir - Qena) As a global mining area (Golden Triangle) } \\
\text { - Development strategy for the border region (Halaib, Abu Ramad, Shlatin, Jabal al-Muqtasheh) (Development integration } \\
\text { with Aswan Province/Red Sea - creation of multi-activity investment opportunities for different potential sites - adoption of } \\
\text { development poles to exploit the potential sites available - creation of a globally competitive development hub to support } \\
\text { the region and its activities - the Red Sea port of Bernice and the proposed port in (Halaib/Abu-Mad) on the Red Sea, } \\
\text { linking them with the coastal road that supports development in the region and its activities. }\end{array}$ \\
\hline $\mathbf{E}$ & $\begin{array}{l}\text { - The development of the Suez Canal hub as a global logistics and industrial center (development of the East Port said } \\
\text { region - development of the new technological and Ismaili valley and the Al Amal suburb - north-west of the Gulf of Suez) } \\
\text { - Development of the North-West Suez Bay and the Seaport of Sokhna and the development of the } 46 \text { thousand feddans } \\
\text { West Suez Bay (industrial zone, maritime activities, service and administrative centers, tourism activities, logistics area). }\end{array}$ \\
\hline $\mathbf{F}$ & $\begin{array}{l}\text { - Development of the axis (Minya-Bouyti-Siwa, Western border) } \\
\text { - } 868,000 \text { acres were reclaimed in western Miny }\end{array}$ \\
\hline
\end{tabular}

\subsection{Requirements for achieving the sustainable development goals in planning new areas in Egypt}

To success of the State plan for the development of new areas of a special nature, it is necessary to integrate the requirements for achieving the various dimensions of sustainable development goals (economic - social environmental and technological-administrative and institutional - urban) [48], are represented in:

-Economic requirements: new areas contribute to facilitating economic performance faster and more effectively through:

-Follow a modern manufacturing policy to advance the industry and interact with modern technology, and create job opportunities with new specifications that absorb the latest technological developments in a sustainable manner. As in the regions of (Marsa Matrouh and the North western Coast, where the Eco-City (El Alamein) was established. It is environmentally compatible; it provides high levels of quality of life and applies the best environmental practices, especially when supplying infrastructure facilities. The Red Sea, where the construction of the mining industrial complex Safaga, Quseir, Qena as a global mining area "Golden Triangle". Completing the development of the Suez Canal hub as a global logistics and industrial center "developing East Port Said, developing the New Valley of Technology and Ismailia and the Al-Amal suburb, northwestern Gulf of Suez).

-Interest in training human resources to increase labor productivity, and exploiting the advantage of research manpower [49].

-Promoting inter-Arab trade and international agreements. Through its three gates (the eastern coast in the Red Sea and

the Suez Canal - the north western coast - the southern borders with Sudan).

-Focusing on small and micro enterprises, and strengthening their relationships with larger projects.

-Stimulating growth in sectors and activities that have a wide absorptive capacity of employment and have an international competitive advantage (raising the growth rate of agricultural activity to $5 \%$ annually - increasing the contribution of the telecommunications sector to the national income to reach $5 \%$ of the country's sovereign return while increasing the volume of electronic commerce by $20 \%$ - Land reclamation projects in North Sinai, Wadi El Natroun, Siwa Oasis, Toshka and east of Al-Uwaynat, Western Minya Plain - developing new means of movement and tourism transport to link tourist destinations to reach the integrated tourist system in the Red Sea, the northwest coast, and Marsa Matrouh)

-Understanding and analyzing the global market forces between integration, intense competition and the intertwining of national economies to attract development activities for Suez Canal region. Development of Suez Canal axis as a global logistical and industrial center "implementation of the scheme of logistical and industrial free trade sites" [29].

\section{-Social requirements:}

-Providing equal opportunities for all groups of society in all fields.

-Establishing special programs for the development of marginalized and poor areas, to empower the poor and the marginalized, raising their capabilities to escape the cycle of poverty through training and qualification. Directing investments towards labour-intensive development projects. Urban and population intensification for national security reasons to face external threats, in the regions of (Sinai - Nubia - Halayeb, Shalateen and Abu Ramad - the south western border - the northern western border).

-Development of human resources, local employment and cultural and social systems in the context of global competition to receive investments and activities [30]. 
-qualify local community for the information society and considering it one of the most important tools of the development process, while preserving the cultural and value heritage of the local community.

\section{-Environmental and technological requirements:}

- The consistency of the environmental policy with the economic policy and the factors of communication and societal communication (the policy of production and sustainable consumption -the rotating economy environmental innovations -....). Thus, it strengthens the links between the main sectors (energy - water - agriculture transport - reducing air pollution).

-The establishment of the Supreme Council for Sustainable Development. Thus, it ensures the implementation and followup of the country's environmental policies and the management and sustainability of natural resources. It ensures, also, the implementation of national executive and guidance programs for solid waste management, integrated environmental management of air quality, nature protection program, environment friendly industrial cities and regions program, safe use of treated wastewater, Nile River protection and water resources program, and environmental education and awareness program [50].

-Promote sustainable use of water resources (developing groundwater in the eastern and western desert and Sinai, protecting them from pollution - developing and strengthening aspects of cooperation with the Nile Basin countries developing rain harvesting technologies along the northern coast), When development strategies and plans are put.

-Restructuring of the solid waste management sector (in an integrated manner, and supporting the recycling sector while encouraging investment).

-Benefiting from the international available finance in the field of climate change, activating international cooperation in the field of clean technology transfer.

-In partnership with civil society organizations, sensitizing the community for the importance of applying sustainable consumption and production patterns to conserve the environment [51].

-Using energy alternatives to secure the needs (new energy, "nuclear energy" - renewable energy, "wind, solar energy, water, biomass energy, tidal energy, and geothermal energy in the ground)" (electrical interconnection projects with the Maghreb and Levant countries in the Sinai - construction of the nuclear plant To generate electricity in Dabaa construction of water pumping stations in East Al-Uwaynat construction of major wind generating stations in connection with the unified national network on the Gulf of Suez).

-Expanding the use of advanced technologies through development of technical education to develop technical industries, information industry, and the service industry, which represent future new leading sectors [52].

\section{-Urban requirements:}

-Providing transportation networks and infrastructure to facilitate the transfer of goods and products to local and global markets (increasing the competitiveness of the Suez Canal to accommodate growth in the global trade movement developing land routes between East and West and Egypt through a group of suspended bridges proposed to be built over the Gulf of Suez - the establishment of new ports on Bahrain Red and Medium - modernizing the National Railways Network and introducing high-speed trains).

-Direct linking between Egypt and the European Union countries to enhance the competitiveness of foreign trade and access to global markets.

-Adopting the strategy of spreading in urban communities of small and medium population sizes, with different patterns and functions (regional services-advanced infrastructureagricultural services-tourism development) in a framework that integrates with existing settlements and new areas.

-Focusing on the relative advantages of spatial specificity and promoting global economic growth through global centers as locomotives for development. Establishing global growth centers on the eastern and northern gates of Egypt compares to and competes with growth centers. There is diversity in the levels of urban centers in new regions, which is represented in (urban cluster centres in Suez and Alexandria - Urban centers suitable to be international gates in Al-Alamein, Port Said, Hurghada, Safaga, Bernice - New National Urban Centers in Sidi Barani, Ras Al-Hikma, Taba, Al-Arish, Toshka, Ras Gharib, Ras Sidr, Ain Sokhna) [1]

-Connecting new areas to a network of roads and developmental axes to achieve sustainable development, (the project of the national plan of road network and the occasional development axes to connect the valley \& delta with the new development east and west areas).

-Sustainable development of new regions based on the exploitation of resources and activating the role of development hubs and new urban communities. They are poles to attract development and encourage mobility and population orientation in the western and eastern desert of the country. That, new areas can accommodate the future population increase by $70 \%[53,54]$.

\section{-Development Department:}

-The trend to attract more global investments and regulatory, legislative, incentive and financing arrangements on the one hand. And, directions to grant powers and human power for Development Department in the local units.

-Encouraging the role of the private sector (local and international investors) in supporting development and serving the community and environment with necessary contributions. This can be achieved within the framework of a set of controls and restrictions that are agreed upon.

-Developing the administrative apparatus of the state and governance, by integration, coordination and bridging the gaps between the various state plans.

-Directing investments to new areas to activate attractions as a national policy.

-Adopting incentive policies to activate the factors that attract residents and investors to the new developed areas (tax exemptions - loans - grants - facilities).

-Establish mechanisms to implement the development plans for new areas (organize planning and development decisions and follow up on their implementation - increase the efficiency of government agencies - develop the management of development sectors - qualify and train the workforce - adhere to the stages, projects and programs defined in the plans increase the participation of the private sector in implementing development projects - prepare Integrated programs for development projects implementation priorities) [18].

-Setting mechanisms for evaluating development plans (heading towards decentralization - defining the methodology of planning studies necessary at all levels and identifying the parties involved in these projects and ways to stimulate investment in them and providing sources of funding - setting up a high-level regional planning body affiliated to the Cabinet backed by an advisory board, a regional research center and regional councils in areas of the proposed development - 
formation of an administration affiliated to the Supreme Council for Planning).

\subsection{Establish a series well pondered set of extend indicators "framework" that could be used to analyze the SDGs in new areas}

To rely on new areas (the developmental scale), to accommodate the requirements of sustainable development. The resources and components of these areas are being used to settle development projects in all sectors to create new prospects for sustainable development. Its efficiency is measured by extend indicators from SDGs:

- Take into account the main natural characteristics and subcomponents of the new regions (location - Area - topography - Geology - morphology - ecology).

- Evaluate the measurement of competitive advantage:

- Number of specialized technical labor. And the size of the educational institutions with the advanced level.

- Provides investment and foreign trade attractions from airports, ports and free zones.

- Areas of environmental sensitivity, rare and protected areas.

- Knowledge and technological areas.

- Natural ingredients of the site and tourist patterns. The most promising and distinguished tourist spots and centers.

- The volume of international tourism demand and the nature of the site.

- Integration with international and regional approaches:

- Regional integration agreements in which Egypt is involved.

- New areas those are capable of attracting investment and activating regional integration agreements.

- Variety in levels of urban centers:

- Urban conglomerate centers (millionaires and new clusters within their scope)

- The centers of architecture are the universal (gates).

- Existing national centers of architecture.

- Regional centers of architecture

- Social and demographic factors are in place to activate development processes in the promising new areas:

- Potential for population assimilation.

- Population densities for the promising new ranges.

- Absorption of projects and areas for the proposed population development.

- The current and proposed workforce.

- The dominant activity of the population in promising new ranges.

- Economic efficiency in the exploitation of development zones [45]:

- The current and proposed economic projects in the new promising ranges of land reclamation, new cities, industrial zones, desert hinterland, and their relationship to available resources.

- Connectivity, access and linkages between existing areas, new development zones and economic projects).

- Number, cost and employment opportunities for proposed economic projects in the new areas.

- Per capita and new areas of the State's investment plan.
- The impact of environmental characteristics, risks and constraints on development processes:

- Water scarcity.

- Mines and explosive objects.

- Topographic and geological characteristics.

- Natural hazards and the existence of certain areas exposed to natural determinants

- Challenges for the continued exploitation of new and renewable sources of energy in new areas.

- Population culture.

- Homogeneity of human elements.

- Resources and environmental components available for development. Potential ingredients and opportunities (land, agricultural, mining, water, tourism, traditional and nontraditional energy sources, proposed population development zones).

- Availability of new and renewable energy utilization capabilities and systems-sensitive project settlement Environmental [55]:

- New areas for wind power generation.

- New areas for generation solar power.

- Locations of traditional and non-conventional sources of uranium and minerals Radiated in Egypt.

- Biomass energy

From the researcher's point of view, these indicators are the basic tool for evaluating projects and development plans for new areas of a special nature to measure improvements and risk assessment.

3.9 Manifestations of improvement in development indicators to achieve sustainable development goals Applying models to new areas in Egypt

The development and desert emergence of the Northwest Coast region are one of the successful experiences of the State in achieving the goals of sustainable development [49]. The following is an analysis of how successful this experience is through an application new standard indicator extend indicators "framework" that could be used to analyze the SDGs in new areas.

- Reclamation and cultivation of areas around loweyedropper by salt water/desalination water.

- create new cities that serve proposed activities while connecting them to a network Suggested regional road [47]. - 50 thousand feddans were reclaimed in Al-Maghra village as part of a development project of 1.5 million feddans as a first stage.

- Create an environmentally compatible city that provides high levels of quality of life Environmental best practices are applied, especially when supplying infrastructure facilities, (Use of new and renewable sources of energy - use of desalination and reuse technology - provision of adequate open and green areas - recycling of solid waste - creation of a sophisticated urban environment - creation of an environmentally friendly industrial zone) [26].

- An integrated development region (agricultural, industrial, tourism, mining, service) that absorbs the greatest future Population growth based on new energy and desalination of seawater.

- Development of the North-West Coast and its desert emergence as a destination for world tourism (Eco-friendly residential city - International leisure center - World Center for healing and War injuries - an International Scientific and University City - Advanced industrial environmental zone) 
- Development of the coastal zone to a depth of $40 \mathrm{~km}$ (agriculture - tourism -housing).

To meet the requirements of sustainable development this will contribute to the improvement of development indicators for the new areas. Table 3 clarifies the improvements in indicators of sustainable development.

Table 3. Indicators of the extent of achieving sustainable development goals

\begin{tabular}{|c|c|c|}
\hline $\begin{array}{c}\text { Improvement in } \\
\text { environmental aspects }\end{array}$ & $\begin{array}{r}\text { improvement in the } \\
\text { aspects }\end{array}$ & Improvement in social aspects \\
\hline $\begin{array}{l}\text { - A privileged location, areas with a special environmental } \\
\text { nature in the oases - knowledge and technology areas in } \\
\text { Mubarak City in Borg El Arab - commercial areas of a } \\
\text { special nature in Alexandria - tourist areas of a special } \\
\text { nature in Marina on the north-western coast and the city of } \\
\text { El Alamein, } \\
\text {-It includes solar energy components, where the average } \\
\text { number of hours of sunshine ranges between } 3000 \text { to } 4000 \\
\text { kilowatt hours per second per year - wind energy, whe re } \\
\text { the average wind speed reaches } 22 \mathrm{~km} / \text { hour - Availability } \\
\text { of sites that include conventional uranium ores in the Sitra } \\
\text { Oasis southwest The Qattara Depression is } 100 \text { parts per } \\
\text { million - the ability to benefit from biomass sources } \\
\text { represented in agricultural and animal wastes in the } \\
\text { generation of bio energy estimated at about } 108,676 \text { tons). } \\
\text {-The technical universities and Mubarak City for Scientific } \\
\text { Research, research institutions, nanotechnology industries, } \\
\text { pharmaceutical industries and medical equipment are } \\
\text { concentrated in Borg El Arab and Alexandria. It also } \\
\text { includes some cities with potential ingredients for } \\
\text { establishing new urban centers to host some specialized } \\
\text { knowledge activities (Dabaa). }\end{array}$ & $\begin{array}{l}\text { - represents the country's investment } \\
\text { plan per capita (2012-2017) (307.199 } \\
\text { pound /per capita) and the region's } \\
\text { share of the country's investment plan } \\
\text { (2012-2017) (909.1million pound). } \\
\text { - The foreign trade and investment } \\
\text { attractions of airports, ports and free } \\
\text { zones include a tourist port, a port for } \\
\text { oil, a port and a fishing port - } \\
2 \text { international airports and } 2 \text { domestic } \\
\text { airports. The region has been } \\
\text { integrated into the national and global } \\
\text { economy, raising GDP from less than } \\
0.5 \% \text { to } 7 \% \text { by exploiting the urban } \\
\text { sprawl of the northwest coast and a } \\
\text { developed area of industrial clusters. }\end{array}$ & $\begin{array}{l}\text { - The region's poverty rate is } 14 \% \\
\text { compared to the Republic's average of } \\
26.7 \% \text { in } 2020 \\
\text { - The unemployment rate is } 7.8 \% \\
\text { compared to the average of the } \\
\text { Republic } 13 \text { The year } 2020 \text {. } \\
\text { - The illiteracy rate is } 19 \% \text { compared to } \\
\text { the average of the Republic } 23.6 \text { The } \\
\text { year } 2020 \text {. } \\
\text { - the Human Development Index } \\
\text { represents } 0.794 \text {. } \\
\text { - The region has an estimated } 11.9 \\
\text { million human resources in the sectors } \\
\text { of (tourism, agriculture, mining, } \\
\text { manufacturing and quarrying, fishing), } \\
\text { as well as potential population } \\
\text { absorption ( } 34 \text { million people), where } \\
\text { population density is reduced (0.006). }\end{array}$ \\
\hline
\end{tabular}

\section{CONCLUSIONS}

The study concluded that the concept of sustainable development has received widespread international attention and use, as its definitions and areas are numerous. For this reason, the research discussed the requirements for achieving sustainable development goals in planning the new areas in Egypt in its various dimensions. Those new areas are considered the new spatial space (outside the Egyptian globe) appropriate to apply and accommodate sustainable development and achieve efficient development returns. Based on the above, a number of results have been reached.

- There are many foundations and indicators for sustainable development. And achieving them requires the existence of a political will for the state as well as willingness among societies and individuals.

-Adopting a national sustainable development strategy that includes all entities, institutions, members of society and those affected by its results in the short and long term, included:

Strategy for dealing with resources and activities: By understanding the nature of the ecosystem and the relationship of different activities to this system, a general framework for dealing with resources and activities can be established. So that, the following is taken into account [56]:

-Ensuring that the minimum levels are not exceeded by negative impacts on the environment. This is achieved by selecting appropriate projects and activities.

-Preserving the biosphere in the natural environment [1].

-Not to deplete or pollute the natural resources of the biosphere beyond the limits of its maximum capacity for selfpurification.

- Preserving social values and the Psychological and spiritual stability of both, individual and society.

-Study the suitability of the site for use, without prejudice to the ecosystem [53].

Strategy for dealing with water resources: Adopting a strategy for water use aims to make the most use of the available water resources, aiming to obtain its highest return through [34]:

- Studying the economics of allocating water for different uses to obtain the largest return for the unit. in addition to identifying the suitable economic activities for the growth of society [9].

-Using agricultural methods and selecting industries that need the least amount of water [49].

-Maximum use of the available water. This requires re-use of water to increase the available water resources (whether wastewater or agricultural) for various purposes. Thus, to limit water losses by developing technology for domestic use, agricultural (using modern irrigation methods), or industrial using industry technology that needs the least amount of water $[3,43]$.

Strategy of energy use: use of non-polluting energy sources, focusing on the use of renewable energy sources, and protecting traditional and renewable energy sources from depletion [51, 52].

Strategy of planning for urban formations: It must take into account the environmental and functional suitability for the site conditions and the most important points that must be focused on in planning that is based on environmental analysis [21].

- Diversity in economic base activities with complementary relationships, with flexibility in their ability to change to achieve self-reliance. These regions also contain natural resources and high-value ingredients (mining - agricultural tourism - water -new and renewable energy) that enable us to stimulate different factors of production (employment opportunities - capital - technology - international agreements 
and trade exchange) [37].

-Focusing on spatially spreading development rather than concentrating investments in large units and their spatial dispersal, which requires similar responses in the spatial distributions of the urban network in order to express the urban ecology that requires creating spatially independent development (new areas far from existing urbanism). The new areas contain urban centers that can play a role at different levels (global - regional - local) [31].

-Reducing environmental and human pressures and reducing the effects of growth and social ability on natural systems. Achieving better gains and benefits in these regions compared to other regions due to the availability (a high and distinct level of available and diversified resources - an easy social structure) that enables them to attract investments. Also, they contribute to the formulation of influential decisions in other regions and advance the wheel of development.

-Develop a mechanism for identifying indicators to measure the extent of monitoring and evaluation of performance [57].

-Administrative and legislative restructuring and emphasis on the principle of participation.

- Providing a cultural structure that is compatible with society by changing consumption patterns and reducing waste and recycling resources through special social practices. Thus, it clarifies the ability of new regions to create a distinct social structure, responding decisions, political trends and state goals [58].

-The infusion of development elements into new areas in the initial stages, based on government support and the state budget, in providing infrastructure and roads.

-Elaborating developmental role of new areas as an integrated, independent, socio-economic, urban, economic, and urban development entity.

\section{REFERENCES}

[1] Imad, A.G. (2017). Information System in Sustainable Development Strategy in Egypt, Perception, Reality and Hope, Aam Magazine, Saudi Arabia. pp. 26- 38.

[2] UNDP Strategic Plan 2018-2021. http://strategicplan.undp.org.

[3] EEA (European Environment Agency). (2005). Sustainable Use and Management of Natural Resources. EEA Report No 9/2005. EEA, Office for Official Publications of the European Communities (OPOCE). http://reports.eea.europa.eu/eea_report_2005_9/en, accessed on 15 November 2012.

[4] United Nations Department of Economic and Social Affairs, International Migration Report 2015. www.un.org/en/development/desa/population/mi gration/publications/migrationreport/docs/MigrationRep ort2015_Highlights.pdf.

[5] Sioner for Refugees (UNHCR). Global Trends - Forced Displacement in 2016. http://www.unhcr.org/5943e8a34.pdf.

[6] UDPE, Urban Development Plan Egypt 2030. (2016), Ministry of Housing, Utilities and Urban Communities, Urban Planning Authority.

[7] Müller -Eie, D., Bjørnø, L. (2017). The implementation of urban sustainability strategies: Theoretical and methodological implications for researching behavior change. International Journal of Sustainable Development and Planning, 12(5): 894-907.
https://doi.org/10.2495/SDP-V12-N5-894-907

[8] United Nations. (2013). World economic and social survey 2013: Sustainable development challenges. New York, NY, USA. https://www.un.org/en/development/desa/publications/ world-economic-and-social-survey-2013-sustainabledevelopment-challenges.html, accessed on Nov. 3, 2020.

[9] Chen, C., LeGates, R., Fang, C. (2019). From coordinated to integrated urban and rural development in China's megacity regions. Journal of Urban Affairs, 41(2):

150-169. https://doi.org/10.1080/07352166.2017.1413285

[10] Parpas, D.S., Savvides, A.I. (2020). On the determinants of a successful, sustainable-driven adaptive reuse: A multiple regression approach. International Journal of Sustainable Development and Planning, 15(1): 1-13. https://doi.org/10.2495/SDP-V15-N1-1-13

[11] Rajeh, A.Z. (2007). Egyptian Urbanism Monitor developments in Egypt Land in the late twentieth century and explore future paths up to 2020. Academic Library. 132-147.

[12] UN Habitat. (2013). State of the World's Cities. Nairobi, Kenya: UN Habitat. https://sustainabledevelopment.un.org/content/documen ts/745habitat.pdf, accessed on Nov. 3, 2020.

[13] Mensah, J. (2019). Sustainable development: Meaning, history, principles, pillars, and implications for human action: Literature review. Cogent Social Sciences, 5(1). https://doi.org/10.1080/23311886.2019.1653531

[14] Oltmann, S.M. (2016). Qualitative interviews: A methodological discussion of the interviewer and respondent contexts. In Forum: Qualitative Social Research, 17(2). http://dx.doi.org/10.17169/fqs17.2.2551

[15] Purvis, B., Mao, Y., Robinson, D. (2019). Three pillars of sustainability: In search of conceptual origins. Sustainability Science, 14(3): 681-695. https://doi.org/10.1007/s11625-018-0627-5

[16] Counsell, D., Haughton, G. (2006). Sustainable development in regional planning: The search for new tools and renewed legitimacy. Geoforum, 37(6): 921-931. https://doi.org/10.1016/j.geoforum.2006.02.001

[17] Salem, M., Tsurusaki, N., Divigalpitiya, P., Kenawy, E. (2020). An effective framework for monitoring and measuring the progress towards sustainable development in the peri-urban areas of the greater Cairo region, Egypt. World, 1(1): 1-19. https://doi.org/10.3390/world1010001

[18] Rahma, H., Fauzi, A., Juanda, B., Widjojanto, B. (2019). Development of a composite measure of regional sustainable development in Indonesia. Sustainability, 11(20): 5861. https://doi.org/10.3390/su11205861

[19] Christen, M., Schmidt, S. (2012). A formal framework for conceptions of sustainability - a theoretical contribution to the discourse in sustainable development. Sustainable Development, 20(6): 400-410. https://doi.org/10.1002/sd.518

[20] Kuhndt, M., Tessema, F., Herrndorf, M. (2008). Global value chain governance for resource efficiency building. Sustainable consumption and production bridges across the global sustainability divides. Environmental Research, Engineering and Management, 3(45): 33-41.

[21] European Commission. (2018). Indicators for sustainable cities. vol. 2015, Brussels, Belgium. 
https://op.europa.eu/en/publication-detail/-

/publication/cbaa6e59-437c-.

[22] Kondyli, J. (2010). Measurement and evaluation of sustainable development. A composite indicator for the islands of the North Aegean region, Greece. Environmental Impact Assessment Review, 30(6): 347356. https://doi.org/10.1016/j.eiar.2009.08.006

[23] Lemke, C., Bastini, K. (2020). Embracing multiple perspectives of sustainable development in a composite measure: The Multilevel Sustainable Development Index. Journal of Cleaner Production, 246.

[24] Ameen, R.F.M., Mourshed, M. (2019). Urban sustainability assessment framework development: The ranking and weighting of sustainability indicators using analytic hierarchy process. Sustainable Cities and Society, $\quad 44$ : 356-366. https://doi.org/10.1016/j.scs.2018.10.020

[25] Polido, A., Ramos, T.B. (2015). Towards effective scoping in strategic environmental assessment. Impact Assessment and Project Appraisal, 33(3): 171-183. https://doi.org/10.1080/14615517.2014.993155

[26] Jenkins, T.N. (2000). Putting postmodernity into practice: Endogenous development and the role of traditional cultures in the rural development of marginal regions. Ecological Economics, 34(3): 301-313. https://doi.org/10.1016/S0921-8009(00)00191-9

[27] Beatley, T., Manning, K. (1997). The Ecology of Place: Planning for Environment, Economy and Community. Washington, D.C.: Island Press. https://doi.org/10.5860/choice.35-5793

[28] Ministry of Housing- Utilities and Urban Communities. (2018). Sustainable Development Strategy Egypt's Vision 2030, General Authority for Urban Planning.

[29] Ministry of Housing- Utilities and Urban Communities. (2013). The Strategic Vision for the Comprehensive Development in Egypt 2052, (GOPP).

[30] TADAMUN. (2016). Planning [In] Justice: Spatial Analysis for Urban Cairo. Cairo. http://www.tadamun.co/wpcontent/uploads/2018/09/PlanninginJustice_.

[31] Ministry of Economic Development. (2009). Strategic Plan for Western desert within the framework of development axes concept.

[32] Al-Ahram Centre for Future Studies. (2009). The Egyptian Desert Development, Creating Distinguished Areas and Sustainable Cities.

[33] Tarabay, A.G.B., González-Villela, R. (2018). The environmental added value of water: A proposal. International Journal of Sustainable Development and Planning, 13(3): 406-417. https://doi.org/10.2495/SDPV13-N3-406-417

[34] Teixid-Figueras, J., Duro, J.A. (2015). International ecological footprint inequality: A methodological review and some results. Environmental \& Resource Economics, 60(4): 607-631. https://doi.org/10.1007/s10640-0149784-x

[35] Bayulken, B., Huisingh, D. (2015). A literature review of historical trends and emerging theoretical approaches for developing sustainable cities (part 1). Journal of Cleaner Production, 109:

11-24. https://doi.org/10.1016/j.jclepro.2014.12.100

[36] Hopwood, B., Mellor, M., O’Brien, G. (2005). Sustainable development: Mapping different approaches. Sustainable Development, 13(1): 38-52. https://doi.org/10.1002/sd.244

[37] JICA. (2008). The Strategic Urban Development Master Plan (SDMP) Study for Sustainable Development of the Greater Cairo Region. vol. 1, Ministry of Housing, Utilities and Urban Development.

[38] Ali-toudert, F., Ji, L., Fährmann, L., Czempik, S. (2020). Comprehensive assessment method for sustainable urban development (CAMSUD) - a new multi-criteria system for planning, evaluation and decision-making. Progress in Planning, 140: 100430. https://doi.org/10.1016/j.progress.2019.03.001

[39] Roseland, M. (2000). Sustainable community development: Integrating environmental, economic, and social objectives. Progress in Planning, 54(2): 73-132. https://doi.org/10.1016/S0305-9006(00)00003-9

[40] CAPMAS. (2019). National Report for Monitoring Sustainable development Goals in Egypt 2030. Cairo. https://www.capmas.gov.eg/pdf/SDG.pdf?fbclid=IwAR 1equ2XA5w0OHxb-zn-6i0gRgfV8zbvpXm-

vkGqcibte40YHWlgE3Zyx_U, accessed on Nov. 3, 2020.

[41] Central Bank of Egypt. (2018). Monthly Statistical Bulletin, No. 252, Economic Research Sector, Cairo.

[42] Ministry of Housing- Utilities and Urban Communities, (2006), A future vision for Egypt 2030, (GOPP).

[43] The World Bank. (2008). Towards an urban sector strategy (Vol. 2). Washington, DC, USA. https://openknowledge.worldbank.org/handle/10986/19 4.

[44] Courtney, P., Hill, G., Roberts, D. (2006). The role of natural heritage in rural development: An analysis of economic linkages in Scotland. Journal of Rural Studies, 22(4): https://doi.org/10.1016/j.jrurstud.2006.02.003

[45] Ministry of Housing- Utilities and Urban Communities. (2012). Greater Cairo Urban Development Strategy; Part I: Future Vision and Strategic Directions. Cairo, Egypt: The General Organization for Physical Planning (GOPP).

[46] UN. (2014). World urbanization prospects, the 2011 revision. Population Division, Department of Economic and Social Affairs, United Nations Secretariat, 2014. https://www.un.org/en/development/desa/population/pu blications/pdf/urbanization/WUP2011_Report.pdf.

[47] Markulev, A., Long, A. (2013). On sustainability: An economic approach. Staff Research Note, Productivity Commission, Canberra, 1-23. https://www.pc.gov.au/research/supporting/sustainabilit y/sustainability.pdf.

[48] Salem, S.A., Amer, S.A., Shaw, D., Abdelmotey, E.A. (2020). Developing a substantive sustainability framework for urban planning in desert regions in Egypt. International Journal of Sustainable Development and Planning, 15(7): 991-999. https://doi.org/10.18280/ijsdp.150703

[49] Tuominen, P., Stenlund, O., Marguerite, C., PardoGarcia, N., Grahn, E., Huvilinna, J., Iglar, B. (2017). CITYOPT planning tool for energy efficient cities. International Journal of Sustainable Development and Planning, 12(3): 570-579. https://doi.org/10.2495/SDPV12-N3-570-579

[50] Sen, A. (2013). The ends and means of sustainability. Journal of Human Development and Capabilities, 14(1): 6-20. https://doi.org/10.1080/19452829.2012.747492

[51] Robinson, J. (2004). Squaring the circle? Some thoughts 
on the idea of sustainable development. Ecological Economics, 48(4): 369-384. https://doi.org/10.1016/j.ecolecon.2003.10.017

[52] Salem, M., Tsurusaki, N., Divigalpitiya, P., Osman, T., Hamdy, O., Kenawy, E. (2020). Assessing progress towards sustainable development in the urban periphery: A case of greater Cairo, Egypt. International Journal of Sustainable Development and Planning, 15(7): 971-982. https://doi.org/10.18280/ijsdp.150701

[53] Ministry of Economic Development. (2009). Western Sahara Strategic Plan within the framework the concept of the Development axes.

[54] UNDESA. (2015). World urbanization prospects: The 2014 revision. United Nations Department of Economics and Social Affairs, Population Division: New York, NY, USA.

https://population.un.org/wup/Publications/Files/WUP2 014-Report.pdf.

[55] Mascarenhas, A., Nunes, L.M., Ramos, T.B. (2015). Selection of sustainability indicators for planning: Combining stakeholders' participation and data reduction techniques. Journal of Cleaner Production, 92: 295-307. https://doi.org/10.1016/j.jclepro.2015.01.005

[56] Mori, K., Christodoulou, A. (2012). Review of sustainability indices and indicators: Towards a new City

Sustainability Index (CSI). Environmental Impact Assessment Review, 32(1): 94-106. https://doi.org/10.1016/j.eiar.2011.06.001

[57] John, B., Keeler, L.W., Wiek, A., Lang, D.J. (2015). How much sustainability substance is in urban visions? An analysis of visioning projects in urban planning. Cities, 48: 86-98. https://doi.org/10.1016/j.cities.2015.06.001

[58] Smits, M. (2017). Formulating a capability approach based model to sustain rural sub-Saharan African inhabitant's self-reliance towards their built environment. International Journal of Sustainable Development and Planning, 12(2): 238-251. https://doi.org/10.2495/SDPV12- N2-238-2

\section{NOMENCLATURE}

GDP

HDI

Acres

$\mathrm{mm} / \mathrm{AC}$

$\mathrm{M}$
Gross domestic product The Human Development Index Ancienne measure agraire $=$ fedane Measure of population density Measure of length 